\title{
Nitric Oxide Induces Rapid, Calcium- Dependent Release of Vesicular Glutamate and ATP From Cultured Rat Astrocytes
}

\author{
ANNA BAL-PRICE, ${ }^{1 *}$ ZAHID MONEER, ${ }^{2}$ AND GUY C. BROWN ${ }^{1}$ \\ ${ }^{1}$ Department of Biochemistry, University of Cambridge, Cambridge, U.K. \\ ${ }^{2}$ Department of Pharmacology, University of Cambridge, Cambridge, U.K.
}

\begin{abstract}
KEY WORDS glia; calcium; inflammation; excitotoxicity; neurodegeneration
\end{abstract}
\begin{abstract}
Nitric oxide (NO; $1 \mu \mathrm{M})$ or an $\mathrm{NO}$ donor $(500 \mu \mathrm{M}$ diethylenetriamine-nitric oxide, DETA-NONOate) caused rapid glutamate and ATP release from cultured rat cortical astrocytes. NO-induced glutamate release was prevented by calcium chelators (EGTA or BAPTA-AM) and an inhibitor of vesicular exocytosis (botulinum neurotoxin C, BoTx-C), but not by a glutamate transport inhibitor, L-trans-pyrrolidine-2,4-dicarboxylate (t-PDC), a cyclooxygenase inhibitor (indomethacin), or an inhibitor of soluble guanylate cyclase $1 \mathrm{H}$ $[1,2,4]$ oxadiazolo-[4,3-a]quinoxalin-1-one (ODQ), and was not induced by mitochondrial respiratory inhibitors (myxothiazol or azide). Similarly to glutamate, NO-induced ATP release was also completely blocked by BAPTA-AM and BoTx-C, suggesting again a vesicular, calcium-dependent mechanism of release. Addition of DETA-NONOate $(500 \mu \mathrm{M})$ to fura-2-loaded astrocytes induced a rapid, transient increase in intracellular calcium levels followed by a lower, sustained level of calcium entry. The latter was blocked by gadolinium $(1 \mu \mathrm{M})$, an inhibitor of capacitative $\mathrm{Ca}^{2+}$ entry. Thus, $\mathrm{NO}$ appears to cause rapid exocytosis of vesicular glutamate and ATP from astrocytes by raising intracellular calcium levels. Astrocytes activated by lipopolysaccharide/endotoxin and interferon- $\gamma$ to express inducible NO synthase (iNOS) maintained substantially higher extracellular glutamate levels than nonactivated cells or activated cells treated with an iNOS inhibitor (1400W), but the rate of glutamate uptake by these cells was similar. This suggests that NO from inflammatoryactivated astrocytes causes release of astrocytic glutamate. NO-induced release of astrocytic glutamate and ATP may be important in physiological or pathological communication between astrocytes and neurons. GLIA 40:312-323, 2002. ๑ 2002 Wiley-Liss, Inc.
\end{abstract}

\section{INTRODUCTION}

Physiologically nitric oxide (NO) derived from neuronal (nNOS) or endothelial (eNOS) NO synthase may act as an intercellular messenger between neurons, astrocytes, and other brain cells (Dinerman et al., 1994; Garthwaite and Boulton, 1995; Prast and Philippu, 2001). Pathologically inducible NO synthase (iNOS) may be induced in glia by inflammatory mediators, and the high level of NO produced may contribute to killing neurons in inflammatory, infectious, ischemic, and neurodegenerative diseases (Loihl and Murphy, 1998; Bolanos and Almeida, 1999; Knott et al., 2000). NO has been implicated in most neurodegen- erative diseases (including multiple sclerosis, AIDS dementia, Parkinson's, Huntington's, Alzheimer's, and motor neuron diseases) (Heales et al., 1999; Ignarro, 2000; Murphy, 2000). For example, in Alzheimer's disease, activated microglia and astrocytes expressing

Grant sponsor: the Wellcome Trust; Grant sponsor: Biotechnology and Biological Sciences Research Council (BBSRC); Grant sponsor: Medical Research Council (MRC).

*Correspondence to: Anna Bal-Price, Department of Biochemistry, University of Cambridge, Tennis Court Road, Cambridge, CB2 1QW, U.K.

E-mail: akp26@mole.bio.cam.ac.uk

Received 26 March 2002; Accepted 14 June 2002

DOI 10.1002/glia.10124 
iNOS are found in the amyloid plaques surrounded by dead and dystrophic neurites (Wa et al., 1996; Wallace et al., 1997; Lee et al., 1999). $\beta$-amyloid can induce cultured glia to express iNOS and kill cocultured neurons via NO (Goodwin et al., 1995; Wisniewski et al., 1998) and anti-inflammatory drugs protect against Alzheimer's disease (McGeer and McGeer, 1995; McGeer et al., 1996; Lim et al., 2000).

$\mathrm{NO}$ and iNOS-expressing glia can kill neurons in culture by excitotoxic mechanisms involving extracellular glutamate (Hewett et al., 1994; Leist et al., 1997; BalPrice and Brown, 2001). NO is known to cause rapid glutamate release from neurons (Meffert et al., 1994; Trabace and Kendrick, 2000), which has been attributed either to inhibition of mitochondrial respiration followed by reversal of glutamate uptake (Sequeira et al., 1997; McNaught and Brown, 1998; Bal-Price and Brown, 2001), or to a direct action on synaptic vesicle docking/fusion reactions followed by (calcium-independent) vesicular exocytosis (Meffert et al., 1996).

Astrocytes are now known to have a vesicular pool of glutamate (and possibly ATP) that is rapidly exocytosed in response to agonists that raise intracellular calcium (Parpura et al., 1994; Bezzi et al., 1998; Maienschein et al., 1999; Innocenti et al., 2000; Pasti et al., 2001). The mechanism of calcium-activated exocytosis of vesicular glutamate appears to be similar in astrocytes and neurons (Araque et., 2000; Mazzanti et al., 2001). During the past few years, it has been shown that by releasing glutamate, astrocytes can modulate synaptic transmission and contribute to certain forms of synaptic plasticity (Mazzanti et al., 2001).

NO has been reported to evoke calcium waves in astrocytes, and endogenous NO may be involve in propagation of such waves (Willmott et al., 2000a, 2000b; Bowman et al., 2001). Calcium waves may propagate between astrocytes via gap junctions or via extracellular mediators and may carry information between astrocytes (Scemes, 2000). There is evidence that the extracellular propagation of calcium waves between astrocytes is also mediated by ATP (Cotrina et al., 1998a; James and Butt, 2001). Nanomolar levels of ATP can act at various purinergic receptors on astrocytes, neurons, microglia, and endothelial cells to increase intracellular calcium (James and Butt, 2001). And increases in intracellular calcium can cause ATP release from neurons and astrocytes (Queiroz et al., 1997). The mechanism of ATP release from astrocytes is unclear, but may, as in neurons, be due to calciuminduced exocytosis of vesicular ATP. We set out to test whether NO could cause glutamate and ATP release from astrocytes and, if so, by what mechanism.

\section{MATERIALS AND METHODS Astrocyte and Microglial Cultures}

Primary, mixed glial cell cultures were prepared from the cerebral cortex of 7-day-old rats (Wistar) as previously described (Bal et al., 1994). Briefly, cells isolated from cerebral hemispheres were dissociated in Hanks' balanced salt solution (HBSS) containing $0.25 \%$ trypsin (Sigma, Poole, U.K.) and $0.02 \mathrm{mg} / \mathrm{ml}$ deoxyribonuclease I (Sigma-Aldrich, Steinheim, Germany) and plated at a density of $0.1 \times 10^{6} \mathrm{cells} / \mathrm{cm}^{2}$ in 25 or 75 $\mathrm{cm}^{2}$ culture flasks (Falcon) in DMEM with $10 \%$ of fetal calf serum. For measurements of $\left[\mathrm{Ca}^{2+}\right]_{\mathrm{i}}$, the cells were grown on coverslips $(9 \times 22 \mathrm{~mm})$. At confluency (12-14 days in vitro, DIV), primary glial cultures were used to isolate microglial cells as previously described (Taupenot et al., 1996). Briefly, mixed glial cells (cultured on the coverslips or in the flasks) were shaken to dislodge microglia that were loosely attached to the astrocytes. Microglia were purified by preplating for $30 \mathrm{~min}$ into culture flasks $\left(75 \mathrm{~cm}^{2}\right)$ at the density $0.1 \times 10^{6}$ cells/ $\mathrm{cm}^{2}$ and then the contaminating cells were removed by changing the medium. Microglia were maintained in astrocyte-conditioned medium (medium collected from astrocytic cultures after 2 days and spun down) mixed $1: 1 \mathrm{v} / \mathrm{v}$ with fresh DMEM (containing $10 \%$ of fetal calf serum). The purity of the astrocytic cultures was determined (after isolation of microglia) in sister cultures immunocytochemically with OX-42 (microglial marker, an anti-CR3 complement receptor antibody; Serotec, Oxford, U.K.), anti-GFAP antibody (an astrocytic marker; AutogenBioclear, Calne, U.K.), anti-NeuN (neuron-specific nuclear protein; Chemicon, Temecula, CA), and anti-Ox7 (the cell surface molecule Thy1.1, specifically expressed on fibroblasts; Department of Pathology, University of Oxford). The purity of microglial cultures was assessed for the presence of microglia and astrocytes only. The cells were fixed in $4 \%$ paraformaldehyde (Sigma) and then incubated with OX-42 or antiGFAP (all at 1:200 dilutions) and visualized using biotinylated antimouse IgG antibodies (1:200 dilution), avidin-biotin-horseradish peroxidase complex, and diaminobenzidine tetrahydrochloride ( $\mathrm{ABC}$ staining system, AutogenBioclear). In the case of Ox-7 and NeuN goat antimouse IgG secondary antibodies were used conjugated to tetra-rhodamine isothiocyanate (IgGTRITC) or to fluoroscein isothiocyanate (IgG-FITC), respectively. As a positive control for anti-NeuN immunocytochemistry, we used neuronal culture of cerebellar granule cells prepared as described before (BalPrice and Brown, 2001) and for anti-Thy1.1 fibroblast culture prepared from the panning plates after Schwann cell purification (Cohen and Wilkin, 1995); $99.0 \% \pm 0.8 \%$ of the cells in microglial cultures were positive for OX-42, marker for macrophage/microglial cell types (GFAP-positive cells were not present). In astrocyte cultures, $97 \%-98 \%$ of cells were anti-GFAPpositive and only $2 \%-3 \%$ cells were OX-42-positive (microglia). Cells anti-NeuN (neuronal marker) or antiThy1.1 (fibroblast marker) - positive were not observed, confirming that neurons or fibroblasts were not present in the astrocytic cultures.

Microglial cultures were used for the determination of glutamate release $24 \mathrm{~h}$ after plating. Cultures of astrocytes were used between 21 and 28 days. When glutamate release was studied using the fluorometric 
method, the microglia or astrocytes were gently trypsinized $\left(0.1 \%\right.$ ) for $2-3 \mathrm{~min}\left(\right.$ at $37^{\circ} \mathrm{C}$ ), the cells were spun down and resuspended in Krebs-Hepes buffer consisting of $1.5 \mathrm{mM} \mathrm{CaCl}_{2}, 5.6 \mathrm{mM}$ glucose, $10 \mathrm{mM}$ HEPES, $4.7 \mathrm{mM} \mathrm{KCl}, 1.2 \mathrm{mM} \mathrm{KH}_{2} \mathrm{PO} 4,1.1 \mathrm{mM}$ $\mathrm{MgSO}_{4}, 118 \mathrm{mM} \mathrm{NaCl}, \mathrm{pH}$ 7.4.

\section{Measurements of $\left[\mathrm{Ca}^{2+}\right]_{i}$ in Astrocyte Cultures}

Confluent cultures of astrocytes (21-28 DIV) on coverslips (after shaking off microglia) were incubated with $2 \mu \mathrm{M}$ fura-2 AM (Molecular Probe, Leiden, The Netherlands; from a stock of $1 \mathrm{mM}$ in anhydrous DMSO) in PBS supplemented with $1 \mathrm{mg} / \mathrm{ml}$ bovine serum albumin (fraction V) and $0.025 \% \mathrm{w} / \mathrm{v}$ Pluronic F-127 (to disperse fura-2 AM in solution). After 120 min at $20^{\circ} \mathrm{C}$ in the dark, coverslips were washed three times with Krebs-Hepes buffer $(\mathrm{pH}$ 7.4) containing 1 $\mathrm{mg} / \mathrm{ml} \mathrm{BSA}$ and kept in the dark at $20^{\circ} \mathrm{C}$ for a further hour. The additional hour was to allow de-esterification of the acetoxymethyl ester of fura-2.

For measurements of intracellular free calcium $\left(\left[\mathrm{Ca}^{2+}\right]_{\mathrm{i}}\right)$ in populations of astrocytes, rectangular coverslips with confluent fura-2-loaded cells were mounted vertically in a $4.5 \mathrm{ml}$ optical methacrylate cuvette. The cuvette was mounted in a Hitachi F4500 spectrofluorimeter with the coverslip at a $30^{\circ}$ angle to the excitation light path. Cells were excited by light of the appropriate wavelengths $\left(\lambda_{\text {ex }} ; 340,359\right.$, and 380 $\mathrm{nm}$ ) using a monochromator, and emitted fluorescence $\left(\lambda_{\text {em }}\right)$ was collected at 0.2 -s intervals at $510 \mathrm{~nm}$. After correction for autofluorescence, calibrations of fluorescence ratios $\left(\mathrm{R}_{340 / 380}\right)$ to cytosolic free $\left[\mathrm{Ca}^{2+}\right]$ were performed using look-up tables created from $\mathrm{Ca}^{2+}$ standard solutions (Molecular Probes). The Krebs-Hepes ( $\mathrm{pH}$ 7.4) bathing the cells was changed by perfusion into the bottom of the cuvette using a peristaltic pump while continuously aspirating medium from just above the coverslip. A circulating water bath maintained the temperature of the perfusate at $37^{\circ} \mathrm{C}$. At the perfusion rate used $(17 \mathrm{ml} / \mathrm{min})$, the medium was exchanged with a half-time of $9.6 \pm 0.3 \mathrm{~s}(\mathrm{n}=3)$. The latency (i.e., the interval between switching saline reservoirs and arrival of the new media at the cuvette) was $9 \mathrm{~s}$. All figures have been corrected for this latency. In some experiments, astrocytes were preincubated with $10 \mu \mathrm{M}$ ODQ (Calbiochem, Nottingham, U.K.) for $10 \mathrm{~min}$ before applying $500 \mu \mathrm{M}$ DETA-NONOate (diethylenetriamine-nitric oxide adduct, also known as NOC-18; RBI, Sigma). In other experiments, $100 \mu$ M PTIO (2-phenyl4,4,5,5-tetramethyl-imidazoline-1-oxyl 3-oxide; Sigma), $10 \mu \mathrm{M}$ verapamil (Calbiochem), or $1 \mu \mathrm{M}$ gadolinium (Sigma) were perfused together with DETA-NONOate $(500 \mu \mathrm{M})$.

\section{Activation of Astrocytes in Culture}

Cultured astrocytes (21-28 DIV, confluent, after shaking off microglia) were activated by exposure to lipopoly- saccharide from Salmonella typhimurium (LPS; $10 \mu \mathrm{g} /$ $\mathrm{ml}$; Sigma) and interferon- $\gamma$ (IFN- $\gamma ; 100$ units/ml, Sigma) in the presence and absence of an iNOS inhibitor $(25 \mu \mathrm{M}$ 1400W; Alexis Biochemicals, Lausen, Switzerland) for $18 \mathrm{~h}$. The medium of astrocytes (DMEM with $10 \%$ of FCS; level of glutamate $85.3 \pm 5.0 \mu \mathrm{M}$ ) was changed just before addition of LPS and IFN- $\gamma$. After $18 \mathrm{~h}$ of exposure to LPS/IFN- $\gamma$ (the activation time), the level of glutamate in the medium was determined by a colorimetric method. Additionally, to determine the capacity of activated astrocytes to remove glutamate from the medium, $100 \mu \mathrm{M}$ glutamate was added to the medium of activated and nonactivated astrocytes, and the level of glutamate in the medium was measured before and 1, 10, $30 \mathrm{~min}$ and 1, 4, and $24 \mathrm{~h}$ after addition of glutamate.

\section{Determination of Glutamate in Culture Media}

Astrocytes for measurements of glutamate release were cultured in $25 \mathrm{~cm}^{2}$ culture flasks for $21-28$ DIV. The volume of the medium in the culture flasks was reduced to $2.5 \mathrm{ml}$ just before exposure of astrocytes to $500 \mu \mathrm{M}$ DETA-NONOate or myxothiazol $(2 \mu \mathrm{M})$ for various intervals of time (5, 30 min or 4 and $24 \mathrm{~h}$ ). After this time, the deproteinized medium of cultured astrocytes was assessed for levels of glutamate by a colorimetric method coupled to glutamate dehydrogenase producing a formazan end product using a commercially available kit (Boehringer Mannheim, Germany). In brief, diaphorase, iodonitrotetrazolium chloride (INT) and conditioned culture medium (after deproteinization) were combined (according to the provided protocol) and incubated for $2 \mathrm{~min}$. Then $3.0 \mathrm{U}$ of glutamate dehydrogenase solution (GDH) was added, and the absorbance was measured at $492 \mathrm{~nm}$ after $15 \mathrm{~min}$ and then every 3 min until the reaction reached steady state. A standard curve was constructed by adding known concentrations of glutamate to culture medium in the range between 1 and $50 \mu \mathrm{M}$. A linear relationship between steady-state absorbance and glutamate concentration was observed up to $20 \mu \mathrm{M}$ of glutamate.

\section{Continuous Assay of Glutamate Release}

NO-induced release of glutamate from astrocytes was also assayed by following the conversion of NADP to NADPH using the fluorometric method of Nicholls et al. (1987). Changes in NADH fluorescence were used as an indirect indicator of glutamate levels. Confluent astrocytes (21-28 DIV) were gently tripsinized (0.1\%), spun down, and resuspended in Krebs-Hepes buffer (2 $\mathrm{ml}$ with $\sim 4.0 \times 10^{6}$ cells). The astrocytes were equilibrated at $37^{\circ} \mathrm{C}$ in a water bath for $\sim 5$ min and then transferred into a temperature-controlled $\left(37^{\circ} \mathrm{C}\right)$ and magnetically stirred cuvette in a Shimadzu model RF 15-01 fluorimeter (excitation $340 \mathrm{~nm}$; emission 460 $\mathrm{nm})$. After a few minutes (2-3 min), $1 \mathrm{mM}$ NADP and $65 \mathrm{U}$ of L-glutamate dehydrogenase were added. Ap- 
proximately $2-4$ min later, glutamate release was initiated by addition of 1,2 , or $4 \mu \mathrm{l}$ of NO-saturated water at $20^{\circ} \mathrm{C}(2 \mathrm{mM})$. NO-saturated water was prepared by bubbling oxygen-free nitrogen through distilled water in a glass vial with a rubber seal, then bubbling with NO gas until the water was NO-saturated. Glutamate release was calibrated by adding a known amount of glutamate at the end of each assay. The relationship between glutamate concentration and NADPH fluorescence was tested by adding 5,10 , or $15 \mu \mathrm{M}$ of glutamate to the assay and was found to be roughly linear over this range. The amplitude of the NADPH fluorescence reached a plateau after $10-20 \mathrm{~s}$.

To determine the effects of indomethacin $(10 \mu \mathrm{M}$; Sigma) or $1 \mathrm{H}-[1,2,4]$ oxadiazolo-[4,3-a]quinoxalin-1-one (10 $\mu \mathrm{M}$; ODQ; Alexis Biochemicals) on NO-induced glutamate release, ODQ or indomethacin was preincubated with astrocytes at $37^{\circ} \mathrm{C}$ in the water bath for 20 min during the equilibration time. NO-induced glutamate release was also measured after preincubation of astrocytes with $25 \mu \mathrm{M}$ 1,2-bis(2-aminophenoxy)ethane-N,N, $\mathrm{N}^{\prime}, \mathrm{N}^{\prime}$,-tetra-acetic acid tetrakis, acetoxymethyl ester (BAPTA-AM; Sigma) for $30 \mathrm{~min}, 15$ or $100 \mu \mathrm{M}$ L-trans-pyrrolidine-2,4-dicarboxylate (t-PDC; Sigma) for $1 \mathrm{~h}, 4 \mathrm{mM}$ EGTA for $1 \mathrm{~h}$, or $1.5 \mathrm{nM}$ botulinum toxin $\mathrm{C}$ (BoTx-C; Calbiochem) for 18 or $24 \mathrm{~h}$ in the incubator $\left(37^{\circ} \mathrm{C} ; 95 \% \mathrm{O}_{2}\right.$ and $\left.5 \% \mathrm{CO}_{2}\right)$. Results are expressed as the amount (in nmol/ $10^{6}$ cells) of glutamate (mean $\pm \mathrm{SD})$ for three of more separate experiments.

\section{Measurement of Extracellular ATP Levels}

ATP levels in the medium were determined luminometrically (Jade luminometer, Labtech International) using an ATP Bioluminescence Assay Kit (Boehringer Mannheim) according to the provided protocol. Briefly, astrocytes (after removing the microglia, 21-28 DIV, cultured in the flasks $25 \mathrm{~cm}^{2}$ ) after replacing the DMEM medium with Krebs-Hepes buffer ( $\mathrm{pH} 7.4)$ were exposed to DETA-NONOate $(0.5 \mathrm{mM})$ for $2.5,5$, or 10 min and samples of the medium were assayed for ATP content using the ATP-dependent light emission of the luciferase-catalyzed oxidation of luciferin. ATP concentrations were expressed as $\mathrm{nM}$ in the medium.

\section{Statistical Analysis}

Data are expressed as mean $\pm \mathrm{SD}$ of the means of 2 independent experiments and were analyzed for significance using ANOVA.

\section{RESULTS \\ Nitric Oxide Donor Induces Glutamate Release From Astrocytes in Culture}

To determine whether nitric oxide can stimulate glutamate release from astrocytes, as it does in the case of

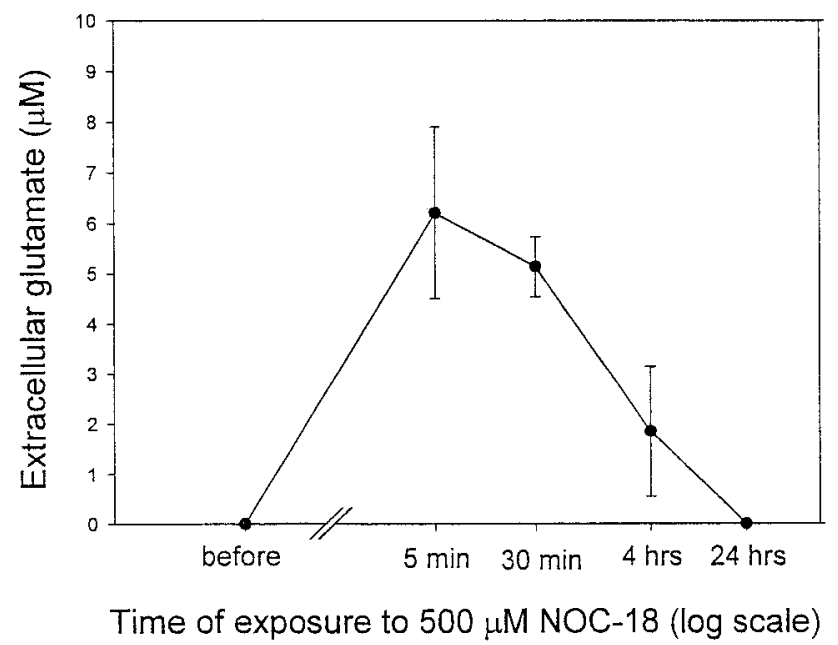

Fig. 1. Exposure of rat cortical astrocytes (21-28 DIV) in culture flasks to DETA-NONOate $(500 \mu \mathrm{M} ; \mathrm{n}=6)$ induced rapid release of glutamate. Values represent means $\pm \mathrm{SD}$.

neurons (Bal-Price and Brown, 2001), cultured rat astrocytes growing in $25 \mathrm{~cm}^{2}$ flasks were exposed to an NO donor (500 $\mu \mathrm{M}$ DETA-NONOate) and the level of glutamate was determined by an enzyme-coupled assay in the medium at various times after addition of DETA-NONOate. Indeed, DETA-NONOate, even after short-term incubation (5 min), caused substantial glutamate release from cultured astrocytes (extracellular glutamate rose from 0.0 to $6.2 \pm 1.7 \mu \mathrm{M}$; Fig. 1.) However, with time, the level of glutamate in the medium of astrocytes exposed to DETA-NONOate $(500 \mu \mathrm{M})$ decreased (after $4 \mathrm{~h}, 1.85 \pm 1.3 \mu \mathrm{M}$ ), disappearing completely after $24 \mathrm{~h}$ (Fig. 1), possibly due to a lower amount of NO released from DETA-NONOate after $24 \mathrm{~h}$, or to downregulation of glutamate release. The release of glutamate was caused by NO released from DETA-NONOate because it was almost completely blocked by $100 \mu \mathrm{M}$ PTIO (an NO scavenger) and the residual product (DETA-NONOate kept at room temperature, exposed to light for a few days) did not cause any significant glutamate release from astrocytes (data not shown). NO-induced glutamate release from neurons and synaptosomes has been attributed to NOinduced inhibition of respiration (McNaught and Brown, 1998), so we tested whether a specific respiratory inhibitor would also cause rapid glutamate release from astrocytes as it does with neurons and synaptosomes. The release of glutamate was not observed after short-term exposure to $2 \mu \mathrm{M}$ myxothiazol (a specific mitochondrial inhibitor that we have previously shown to inhibit respiration completely at this concentration; extracellular glutamate in control was $0.0 \pm 0.0 \mu \mathrm{M}$ and after addition of $2 \mu \mathrm{M}$ myxothiazol was $0.28 \pm$ $0.39,0.92 \pm 0.27,1.7 \pm 2.1 \mu \mathrm{M}$ after 1,10 , and $30 \mathrm{~min}$ of exposure, respectively; $\mathrm{n}=3$ ). This suggests that NO-induced rapid release of glutamate from astrocytes is not mediated by inhibition of respiration. 


\section{NO Induces Rapid Calcium-Dependent Release of Vesicular Glutamate From Astrocytes}

To study the kinetics and mechanism of NO-induced glutamate release, NO-saturated water was injected into a stirred suspension of astrocytes $\left(\sim 4.0 \times 10^{6}\right.$ cells in $2 \mathrm{ml}$ of Krebs-Hepes buffer, $\mathrm{pH} 7.4$, at $37^{\circ} \mathrm{C}$ ) and glutamate release was assayed continuously using a fluorometric method (Nicholls et al., 1987). Indeed, after addition of $\mathrm{NO}$ saturated water $(1,2$, or $4 \mu \mathrm{M}$ $\mathrm{NO}$ ), rapid and dose-dependent release of glutamate from astrocytes was observed (Figs. 2A and 3). Glutamate release was observed immediately after $\mathrm{NO}$ addition and was at least as fast as the response time of the method (a few seconds), but stopped after 10-20 s, presumably because of the rapid decay of $\mathrm{NO}$ in such solutions (Bal-Price and Brown, 2001). In control experiments, in the absence of either L-glutamate dehydrogenase, NADP, or astrocytes, there were no fluorescence changes observed when nitric oxide was added. Glutamate release was mediated by nitric oxide because NO scavenger PTIO $(100 \mu \mathrm{M})$ abolished it almost completely (Fig. 3). NO did not induce glutamate release from cultured microglia (Fig. 3) using the same conditions and the same number of cells, indicating that glutamate release is relatively specific to astrocytes. Interestingly, NO-induced glutamate release was completely blocked by the preincubation of astrocytes with either an extracellular $\mathrm{Ca}^{2+}$ chelator $4 \mathrm{mM}$ EGTA (for $1 \mathrm{~h}$; Figs. 2B and 3) or an intracellular $\mathrm{Ca}^{2+}$ chelator $25 \mu \mathrm{M}$ BAPTA-AM (for $30 \mathrm{~min}$; Figs. $2 \mathrm{C}$ and $3)$. Since in the absence of calcium glutamate release was not observed, these results indicate that the NO-induced glutamate release from astrocytes was calcium-dependent.

As there are studies suggesting that $\mathrm{Ca}^{2+}$-dependent glutamate release from astrocytes can occur by a process resembling neuronal exocytosis, we investigated the effect of BoTx-C (1.5 nM), a specific toxin that blocks the exocytotic release of neurotransmitters in neurons by cleavage of syntaxin (synaptic protein). It has been shown that BoTx-C blocks bradykinin-induced calcium-dependent glutamate release from astrocytes (Jeftinija et al., 1997). To determine whether BoTx-C affects NO-induced glutamate release, astrocytes were incubated with BoTx-C (1.5 nM) for 16 or $24 \mathrm{~h}$ before NO addition as prolonged incubation with toxin is necessary to inhibit glutamate release from astrocytes (Bezzi et al., 1998; Pasti et al., 2001). This prolonged incubation with BoTx-C (16-24 h) did not cause any cell death as tested by Hoechst 33342 and propidium iodide staining to assess whether any apoptotic or necrotic cells, respectively, were present. Pretreatment of the astrocytes with BoTx-C for $16 \mathrm{~h}$ partly decreased NO-induced glutamate release (data not shown), but 24-h incubation completely blocked it (Figs. 2D and 3). This suggests that syntaxin is required for NO-evoked glutamate release and therefore the release is probably due to exocytosis of vesicular glutamate. NO-induced glutamate release was not sig-
A

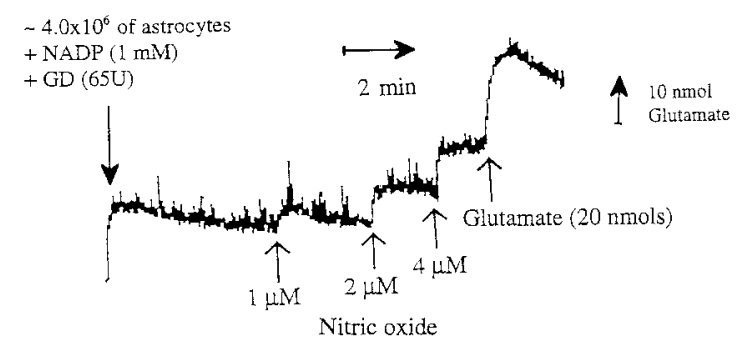

B

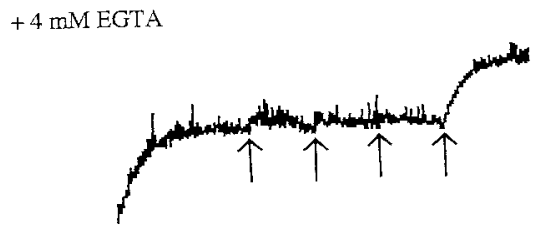

C

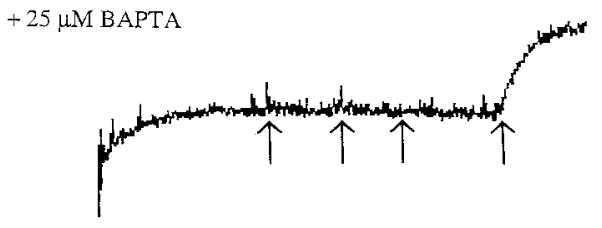

D


Fig. 2. Representative fluorescence traces of glutamate release from rat cortical astrocytes in suspension induced by nitric oxide. Without further additions (control), nitric oxide evoked rapid and dose-dependent release of glutamate from cultured astrocytes (21-28 DIV; A). Preincubation of astrocytes with either extracellular $\mathrm{Ca}^{2+}$ chelator $4 \mathrm{mM}$ EGTA for $1 \mathrm{~h}(\mathbf{B})$ or an intracellular $\mathrm{Ca}^{2+}$ chelator 25 $\mu \mathrm{M}$ BAPTA-AM for $30-40 \mathrm{~min}(\mathbf{C})$ or $1.5 \mathrm{nM}$ botulinum toxin (BoTx-C) for $24 \mathrm{~h}$ (D) blocked completely NO-induced glutamate release from astrocytes. Glutamate release induced by nitric oxide from astrocytes was not affected by preincubation with an inhibitor of the glutamate transporter $100 \mu \mathrm{M}$ t-PDC for $1 \mathrm{~h}(\mathbf{E})$. For each trace, $\sim 4 \times$ $10^{6}$ astrocytes were added to $2 \mathrm{ml}$ of Krebs-Hepes buffer in a fluorimeter cuvette followed by NADP and glutamate dehydrogenase (GD) Subsequent additions of $1 \mu \mathrm{M} \mathrm{NO}, 2 \mu \mathrm{M} \mathrm{NO}, 4 \mu \mathrm{M}$ NO, and $20 \mathrm{nmol}$ of glutamate were made (indicated by the four arrows)

nificantly affected by preincubation of astrocytes with an inhibitor of the glutamate transporter t-PDC (100 $\mu \mathrm{M}$ for $1 \mathrm{~h}$; Figs. $2 \mathrm{E}$ and 3 ), suggesting that glutamate transporters are not required for NO-induced glutamate release from cultured astrocytes. However, after preincubation with t-PDC, NO-induced glutamate release was not significantly dose-dependent. It is possible that the prolonged incubation with $100 \mu \mathrm{M}$ t-PDC $(1 \mathrm{~h})$ may perturb glutamate pools inside and outside 




Fig. 3. Quantification of glutamate release evoked by 1,2 , or $4 \mu \mathrm{M}$ NO from control astrocytes (nontreated; $\mathrm{n}=24$ ) or preincubated with either $25 \mu$ M BAPTA-AM (for 30-40 min; $\mathrm{n}=9$ ), $4 \mathrm{mM} \mathrm{EGTA} \mathrm{(for} 1 \mathrm{~h}$; $\mathrm{n}=9$ ), $100 \mu \mathrm{M}$ t-PDC (for $1 \mathrm{~h} ; \mathrm{n}=6$ ), $1.5 \mathrm{nM}$ botulinum toxin-C (BoTx-C; for $24 \mathrm{~h} ; \mathrm{n}=6$ ), $10 \mu \mathrm{M}$ ODQ (for $20 \mathrm{~min}$; $\mathrm{n}=6$ ), $10 \mu \mathrm{M}$ indomethacin (INDO; for $20 \mathrm{~min}$; $\mathrm{n}=6$ ), or $100 \mu \mathrm{M}$ PTIO $(\mathrm{n}=6)$. Alternatively, the same number of microglia was added but no signif-

the cells, but it is clear that the inhibitor does not block NO-induced glutamate release.

To provide further insights into the mechanism of NO-induced glutamate release, astrocytes were also preincubated with $10 \mu \mathrm{M}$ ODQ (inhibitor of soluble guanylate cyclase) to test whether guanylate cyclase is involved. However, ODQ did not block NO-induced glutamate release from astrocytes, suggesting that guanylate cyclase is not involved (Fig. 3).

It has been reported that glutamate release from astrocytes can be blocked by indomethacin, a cyclooxygenase inhibitor (Bezzi and Volterra, 2001). However, in our studies, preincubation of astrocytes with indomethacin $(10 \mu \mathrm{M})$ had no effect (Fig. 3), suggesting that generation of prostaglandins is not involved in NOinduced glutamate release from astrocytes. Indomethacin, ODQ, or BoTx-C did not affect the glutamate assays on their own and did not cause any cell death after the preincubation time as estimated by trypan blue staining (data not shown).

Release of glutamate was not observed after addition of $2 \mathrm{mM}$ azide (an inhibitor of cytochrome oxidase; data not shown), suggesting again that NO-induced rapid release of glutamate from astrocytes was not mediated by inhibition of respiration.

\section{NO Induces Rapid Calcium-Dependent Release of Vesicular ATP From Astrocytes}

To test whether nitric oxide could also stimulate release of ATP, as it does in the case of glutamate, cultured rat astrocytes (after shaking off microglia) were exposed to $500 \mu \mathrm{M}$ DETA-NONOate for $2.5,5$, and $10 \mathrm{~min}$ and the level of ATP was measured in icant glutamate release was seen in response to 1,2 , or $4 \mu \mathrm{M}$ NO. Glutamate levels were measured using a continuous fluorometric assay. Results are expressed as the amount of glutamate released in $\mathrm{nmol} / 10^{6}$ cells means $\pm \mathrm{SD}$. Levels that are statistically significantly different from control astrocytes treated with 1,2 , or $4 \mu \mathrm{M}$ NO (first columns) are marked $* P<0.05, * * P<0.01$, and $* * * P<0.001$.

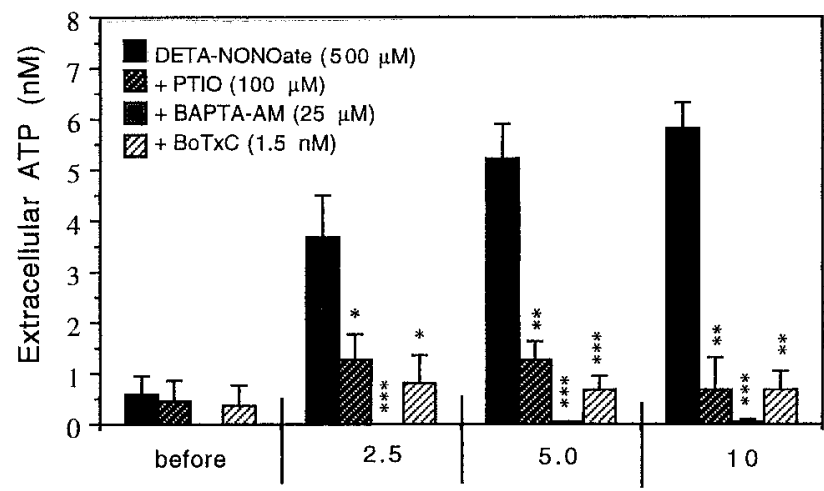

Time after addition of DETA-NONOate (min)

Fig. 4. Time course of $500 \mu \mathrm{M}$ DETA-NONOate-induced ATP release from $\sim 1.0 \times 10^{6}$ of rat cortical astrocytes (21-28 DIV) preincubated with either PTIO $(100 \mu \mathrm{M} ; \mathrm{n}=6), 25 \mu \mathrm{M}$ BAPTA-AM $(\mathrm{n}=6)$, $1.5 \mathrm{nM}$ botulinum toxin-C (BoTx-C; $\mathrm{n}=6$ ), or without additional treatment $(\mathrm{n}=9)$. ATP levels were determined luminometrically. Results are expressed as concentration ( $\mathrm{nM}$ in the medium) means \pm SD. $* P<0.05, * * P<0.01$, and $* * * P<0.001$ statistical significance of difference from ATP release after the same time of DETA-NONOate treatment, but with no other additions (black bars).

Krebs-Hepes buffer (pH 7.4). Indeed, DETA-NONOate caused a rapid increase of extracelluar ATP and after 10 min was about 10 -fold higher $(5.8 \pm 0.7 \mathrm{nM})$ than the basal level $(0.5 \pm 0.4 \mathrm{nM}$; Fig. 4$)$. The ATP release was caused by nitric oxide since $100 \mu \mathrm{M}$ PTIO (NO scavenger) prevented it almost completely (Fig. 4).

Similarly to NO-mediated glutamate release, ATP release was also entirely calcium-dependent since 30-min preincubation of cultured astrocytes with BAPTA-AM $(25 \mu \mathrm{M})$ completely blocked the ATP release (Fig. 4). Since these results suggested that the vesicular mechanisms could be involved in NO-medi- 
ated ATP release, the astrocytes were exposed to BoTx-C (1.5 nM). Prolonged treatment with BoTx-C $(24-28 \mathrm{~h})$ before exposure to DETA-NONOate $(0.5$ $\mathrm{mM}$ ) blocked NO-induced ATP release (Fig. 4). These results indicate that NO-induced ATP release from cultured astrocytes was mediated by calcium-dependent vesicular release, as in the case of NO-induced glutamate release. Exposure of astrocytic culture to DETA-NONOate $(500 \mu \mathrm{M})$ for $2.5,5.0$, or $10 \mathrm{~min}$, BoTx-C (1.5 nM) for $28 \mathrm{~h}$, or BAPTA (25 $\mu \mathrm{M})$ for $30 \mathrm{~min}$ did not cause any cell death as determined by propidium iodide and Hoechst 33342 staining.

\section{Nitric Oxide Induces a Rapid Biphasic Increase in Intracellular Calcium $\left(\left[\mathrm{Ca}^{2+}\right]_{\mathrm{i}}\right)$}

To determine whether NO increased intracellular calcium, astrocytes cultured on coverslips loaded with fura-2 were perfused with DETA-NONOate $(500 \mu \mathrm{M})$ and intracellular calcium levels were monitored. The mean resting $\left[\mathrm{Ca}^{2+}\right]_{\mathrm{i}}$ in astrocytes was $38.5 \pm 15.3 \mathrm{nM}$ $(\mathrm{n}=15$; Fig. 6). Application of $500 \mu \mathrm{M}$ DETA-NONOate resulted in a rapid, transient (1-3 min) increase in $\left[\mathrm{Ca}^{2+}\right]_{\mathrm{i}}$ (to $141.2 \pm 17.8 \mathrm{nM}$; Figs. 5 and 6 ) followed by return to a lower, but still elevated, level of calcium $(63.1 \pm 8.3 \mathrm{nM})$ sustained for at least 10 min (Figs. 5 and 6). The observed increase in $\left[\mathrm{Ca}^{2+}\right]_{\mathrm{i}}$ in astrocytes was indeed induced by $\mathrm{NO}$ and was completely and rapidly reversible; after addition of $100 \mu \mathrm{M}$ PTIO (NO scavenger), the level of $\left[\mathrm{Ca}^{2+}\right]_{\mathrm{i}}$ dropped to the level observed before DETA-NONOate application (Figs. 5A and 6).

To test whether the nitric oxide-induced $\left[\mathrm{Ca}^{2+}\right]_{\mathrm{i}}$ rise resulted from calcium influx across the plasma membrane or mobilization from intracellular stores, calcium was removed from Krebs-Hepes buffer prior to DETANONOate application. In this case, only a transient increase in $\left[\mathrm{Ca}^{2+}\right]_{\mathrm{i}}$ was observed after DETA-NONOate application (Fig. 5E), suggesting that extracellular calcium was required for the generation and maintenance of the sustained $\left[\mathrm{Ca}^{2+}\right]_{\mathrm{i}}$ plateau observed during continued presence of extracellular calcium. The specific inhibitor of capacitative calcium entry (CCE) $1 \mu \mathrm{M}$ gadolinum (Moneer and Taylor, 2002) immediately blocked the increase in $\left[\mathrm{Ca}^{2+}\right]_{\mathrm{i}}$ observed after DETANONOate application (Fig. 5B). These results suggest that the biphasic $\left[\mathrm{Ca}^{2+}\right]_{\mathrm{i}}$ increase induced by nitric oxide could be separated into two components: an initial transient component that is due to calcium mobilization from intracellular stores and a plateau component sustained by CCE.

Since several studies have described the expression of voltage-activated calcium channels in astrocytes, we tested whether nitric oxide-induced $\mathrm{Ca}^{2+}$ entry could be partially mediated by voltage-gated $\mathrm{Ca}^{2+}$ channels. However, $10 \mu \mathrm{M}$ verapamil (blocker of L-type $\mathrm{Ca}^{2+}$ channels) did not affect the $\left[\mathrm{Ca}^{2+}\right]_{\mathrm{i}}$ plateau induced by DETA-NONOate (Figs. 5C and 6), suggesting that NOinduced $\mathrm{Ca}^{2+}$ entry into astrocytes was not mediated by voltage-sensitive $\mathrm{Ca}^{2+}$ channels. To study further the mechanisms of NO-induced $\left[\mathrm{Ca}^{2+}\right]_{i}$ increase, the astrocytes were preincubated for $10 \mathrm{~min}$ with $10 \mu \mathrm{M}$ ODQ (guanylate cyclase inhibitor) before DETANONOate application to determine whether NO-induced calcium entry into the cells could be mediated by the cGMP pathway. However, preincubation of astrocytes with ODQ did not have any influence on NOinduced increase of $\left[\mathrm{Ca}^{2+}\right]_{\mathrm{i}}$ (Figs. 5D and 6), indicating that the NO-mediated $\mathrm{Ca}^{2+}$ entry is cGMP-independent.

\section{Nitric Oxide Released From LPS/IFN- $\gamma$-Activated Astrocytes Causes High Extracellular Glutamate Levels But Has Little Effect on Glutamate Uptake}

Since exogenously added NO caused rapid glutamate release, we tested whether endogenously produced NO from cytokine-activated astrocytes could elevate extracellular glutamate levels.

Astrocytes (21-28 DIV, confluent) were exposed for $18 \mathrm{~h}$ to LPS and IFN- $\gamma$, which leads to high levels of NO production from iNOS (Bal-Price and Price, 2001) in the presence or absence of an iNOS inhibitor $1400 \mathrm{~W}$ $(25 \mu \mathrm{M})$. After $18 \mathrm{~h}$ of activation, glutamate levels in the medium were measured using a colorimetric method and compared with nonactivated astrocytes. In the case of activated astrocytes, high levels of glutamate were present in the medium $(7.38 \pm 1.6 \mu \mathrm{M})$ after $18 \mathrm{~h}$ of activation as compared with very low level of glutamate in the medium of control astrocytes $(0.43 \pm$ $0.06 \mu \mathrm{M}$; Fig. 7). In the presence of the iNOS inhibitor (25 $\mu \mathrm{M} 1400 \mathrm{~W})$, glutamate was still present in the medium but at a lower level $(3.72 \pm 0.6 \mu \mathrm{M})$. These results are compatible with NO from activated astrocytes inducing glutamate release. However, the same result could be caused by a decreased capacity of activated astrocytes for glutamate uptake.

To determine whether nitric oxide produced by the proinflammatory cytokine-activated astrocytes could attenuate astrocytic capacity for glutamate uptake, $100 \mu \mathrm{M}$ exogenous glutamate from stock solution was added to the astrocytes after $18 \mathrm{~h}$ of activation in the presence and absence of iNOS inhibitor $(25 \mu \mathrm{M}$ $1400 \mathrm{~W}$ ), and then samples of the medium were taken at various intervals of time $(1,10,30 \mathrm{~min}$ or 1 , 4 , and $24 \mathrm{~h}$ ) and glutamate content was measured. In the control cultures, glutamate concentrations showed a rapid initial decline; within 30 min glutamate concentrations dropped to $6.7 \pm 1.46 \mu \mathrm{M}$ (Fig. 7) and after $1 \mathrm{~h}$ reached values below $1 \mu \mathrm{M}$. These data show that control astrocytes were capable of taking up glutamate rapidly and efficiently. LPS/IFN- $\gamma$-activated astrocytes removed glutamate from the medium at a similar rate to nonactivated (or $1400 \mathrm{~W}$-treated) astrocytes. However, the level of glutamate in the medium of activated astrocytes was always higher than in the control culture at each time point both before and after 
glutamate addition (Fig. 7). After 24 h, glutamate was still present in the medium of activated astrocytes $(7.8 \pm 1.5 \mu \mathrm{M})$ at concentration similar to that prior the addition of $100 \mu \mathrm{M}$ glutamate. In the presence of the iNOS inhibitor $(1400 \mathrm{~W})$, glutamate uptake was again similar, but after $24 \mathrm{~h}$ the glutamate level returned to

\section{DETA-NONOate}

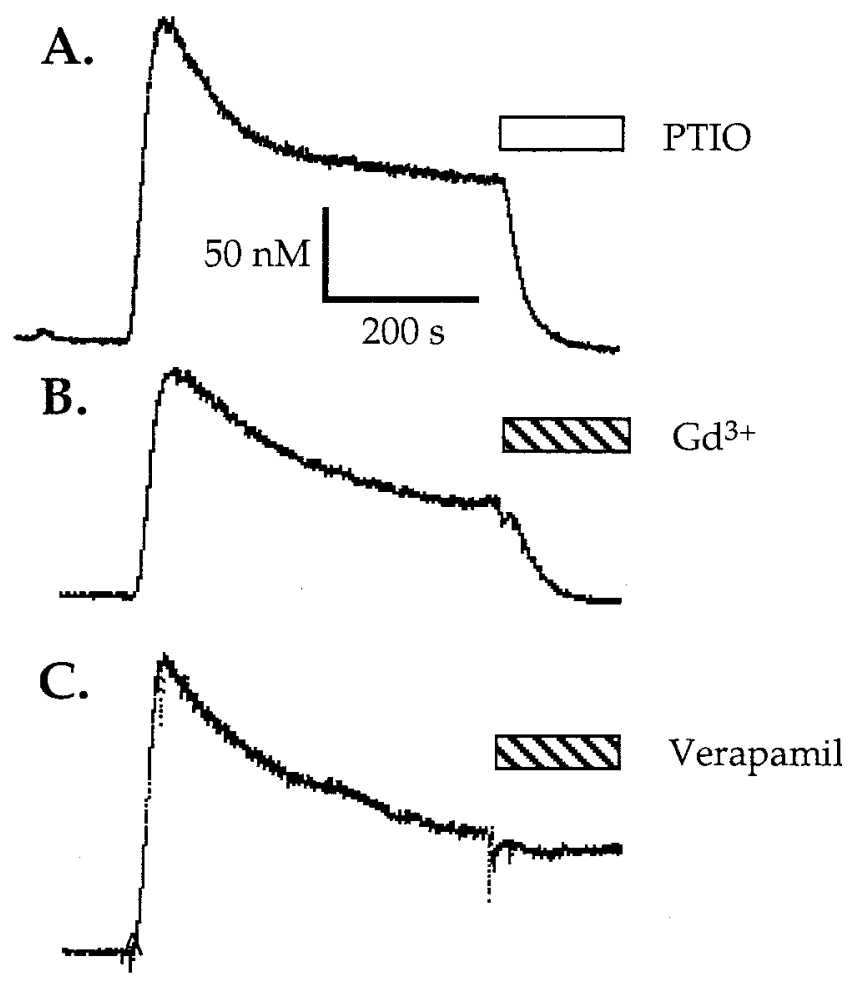

D.



E.

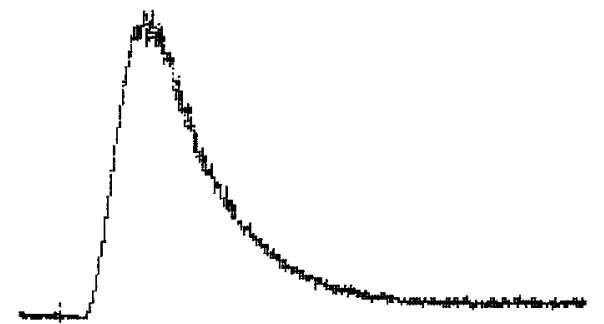

a steady-state level lower than in the absence of $1400 \mathrm{~W}$ (but higher than in nonactivated astrocytes).

These results suggest that the elevated extracellular glutamate level maintained by activated astrocytes is due to increased glutamate release, with little or no change in glutamate uptake.

\section{DISCUSSION}

It has previously been shown that NO can cause acute glutamate release from neurons or synaptosoms (Sequeira et al., 1997; McNaught and Brown, 1998; Bal-Price and Brown, 2001), and we have attributed this to NO inhibition of mitochondrial respiration causing a fall in ATP, inhibition of the sodium pump, and reversal of the glutamate transporter. Evidence for this mechanism was that the time, oxygen, and NO dependence of glutamate release and respiratory inhibition were similar, glutamate release was calcium-independent, and specific respiratory inhibitors caused a similar fall in ATP and glutamate release (McNaught and Brown, 1998; Bal-Price and Brown, 2001). Sequeira et al. (1997) found a similar calcium-independent glutamate release from synaptosomes induced by NO, associated with a decrease in ATP/ADP ratio and inhibited by t-PDC (an inhibitor of the glutamate transporter). In contrast, we find here that NO-induced glutamate release from astrocytes is completely calcium-dependent and is not replicated by respiratory inhibitors. The reason NO does not cause energy depletion-induced glutamate release from astrocytes is probably because although it inhibits astrocytic respiration (Brown et al., 1995), it does not cause a fall in astrocytic ATP (Bal-Price and Brown, 2001), presumably because of the relatively high glycolytic capacity of astrocytes (Pauwels et al., 1985; Peuchen et al., 1997). Our finding that t-PDC did not have any significant effect on NOinduced glutamate release from astrocytes confirms that this release is not mediated by reversal of the glutamate transporter.

In the case of neurons, it has been proposed that NO causes glutamate release by directly modifying the exocytotic machinery of synaptic vesicles. This was based on the finding that neuronal glutamate release induced by NO was calcium-independent but inhibited by butu-

Fig. 5. Representative traces of NO-induced increase in intracellular calcium $\left[\mathrm{Ca}^{2+}\right]_{\mathrm{i}}$ in astrocytes after perfusion with $500 \mu \mathrm{M}$ DETANONOate. The increase was caused by NO released from DETANONOate because $100 \mu \mathrm{M}$ PTIO (NO scavenger) completely reversed the increase $(\mathbf{A})$. The sustained component of $\mathrm{Ca}^{2+}$ entry was also inhibited by the inhibitor of capacitative calcium entry, $1 \mu \mathrm{M}$ gadolinium $\left(\mathrm{Gd}^{3+} ; \mathbf{B}\right)$, but was unaffected by the L-type $\mathrm{Ca}^{2+}$ channel inhibitor, $10 \mu \mathrm{M}$ verapamil $(\mathbf{C})$ or by the soluble guanylate cyclase inhibitor, $10 \mu \mathrm{M}$ ODQ (D). The sustained level of $\left[\mathrm{Ca}^{2+}\right]_{\mathrm{i}}$ induced by DETA-NONOate $(500 \mu \mathrm{M})$ was abolished by removal of extracellular $\mathrm{Ca}^{2+}$, whereas the initial mobilization was unaffected $(\mathbf{E})$. The measurements of $\left[\mathrm{Ca}^{2+}\right]_{\mathrm{i}}$ were performed in fura-2-loaded astrocytes using one coverslip $\left(\sim 0.15 \times 10^{6}\right.$ cells $)$. Bars represent the time of perfusion with the indicated substances. DETA-NONOate $(500 \mu \mathrm{M})$ was used in all the above experiments. 


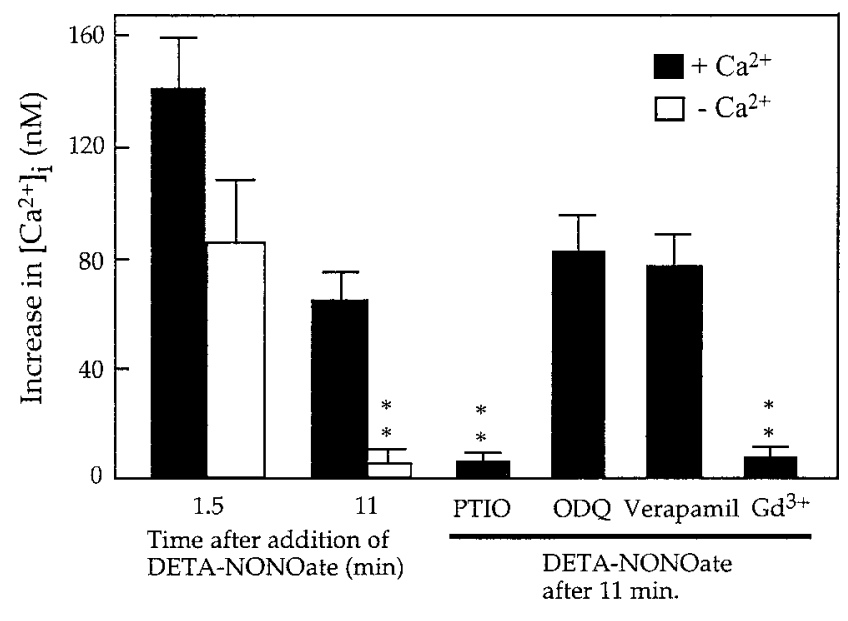

Fig. 6. Quantification of the increase in intracellular calcium induced by DETA-NONOate $(500 \mu \mathrm{M})$ in cultured rat astrocytes in the absence $(\mathrm{n}=24)$ or presence of $100 \mu \mathrm{M}$ PTIO $(\mathrm{n}=3), 10 \mu \mathrm{M}$ ODQ $(\mathrm{n}=$ $6), 10 \mu \mathrm{M}$ verapamil $(\mathrm{n}=3), 1 \mu \mathrm{M}$ gadolinium $\left(\mathrm{Gd}^{3+}\right)(\mathrm{n}=3)$, or in the absence of extracellular $\mathrm{Ca}^{2+}(\mathrm{n}=3)$. Values represent means $\pm \mathrm{SD}$. ** $P<0.01$ from calcium concentration in astrocytes exposed to DETA-NONOate $(500 \mu \mathrm{M})$ alone for $11 \mathrm{~min}$ in Krebs-Hepes buffer with $\mathrm{Ca}^{2+}$.

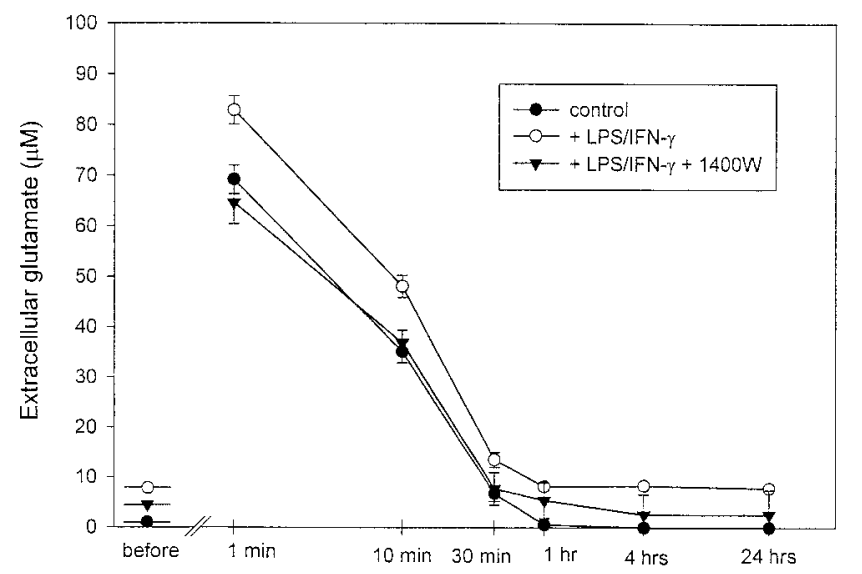

Time after addition of $100 \mu \mathrm{M}$ glutamate (log scale)

Fig. 7. Extracellular glutamate levels before and after addition of $100 \mu \mathrm{M}$ glutamate to the medium of nonactivated (control) and LPS IFN- $\gamma$-activated astrocytes in the presence or absence of iNOS inhibitor $1400 \mathrm{~W}(25 \mu \mathrm{M} ; \mathrm{n}=3)$. Samples of media were taken at the points indicated and the glutamate content was determined. Note that the levels of glutamate in the medium of astrocytes prior to glutamate additions were $0.43 \pm 0.06 \mu \mathrm{M}$ (control, nonactivated), $7.38 \pm 1.6 \mu \mathrm{M}$ (activated in the absence of $1400 \mathrm{~W} ; P<0.001$ from control), and $3.72 \pm 0.6 \mu \mathrm{M}$ (activated in the presence of $1400 \mathrm{~W} ; P<0.01$ from activated without $1400 \mathrm{~W})$. Twenty-four hours after glutamate addition $(100 \mu \mathrm{M})$, the levels of glutamate were $0.0 \mu \mathrm{M}$ in control culture, $7.8 \pm 1.5 \mu \mathrm{M}$ in the medium of activated astrocytes without $1400 \mathrm{~W}$ $(P<0.001$ from control culture), and $2.58 \pm 0.8 \mu \mathrm{M}$ in activated astrocyte with $1400 \mathrm{~W}(P<0.05$ from activated astrocytes without $1400 \mathrm{~W})$. Values represent means $\pm \mathrm{SD}$.

linum neurotoxins $\mathrm{A}, \mathrm{C}$, and $\mathrm{F}$ and associated with covalent modifications of vesicle proteins (Meffert et al., 1996). However, our finding that NO-induced glutamate (and ATP) release in astrocytes is completely calcium-dependent suggests that such direct mecha- nisms are not relevant in astrocytes, at least in our conditions.

Astrocytes have a glutamate release mechanism similar to that of neurons, mediated by exocytosis of vesicles loaded with glutamate (Araque et al., 2000; Bezzi and Volterra, 2001). This exocytosis is triggered by increased cytosolic calcium (often in the form of calcium waves) (Bezzi et al., 1998; Araque et al., 2000) and is inhibited by botulinum neurotoxin C or B (Jeftinja et al., 1997; Araque et al., 2000). As we found that NO-induced glutamate and ATP release from astrocytes were calcium-dependent and inhibited by BoTx-C, it seems likely that this release is mediated by vesicular exocytosis.

It has previously been shown that NO induces acute increases of cytosolic calcium (and calcium waves) in astrocytes, possibly via activation of soluble guanylate cyclase (Willmott et al., 2000a). In our present studies, we show that the application of DETA-NONOate to fura-2-loaded astrocytes caused a very rapid increase of $\left[\mathrm{Ca}^{2+}\right]_{\mathrm{i}}$, but this was not blocked by ODQ (a soluble guanylate cyclase inhibitor), suggesting that soluble guanylate cyclase was not involved. The discrepancy between our studies and the results described by Willmot et al. (2000a) is possibly due to the fact that in their studies LY83583 was used to block guanylate cyclase activity, but this compound is known also to inactivate nitric oxide (Barbier and Lefebvre, 1992), in contrast to ODQ, which does not affect NO levels. cGMP-independent mechanisms of NO-induced increase in $\left[\mathrm{Ca}^{2+}\right]_{\mathrm{i}}$ were also shown in C6 glioma (Bowman et al., 2001) and Bergmann glial cells (Matyash et al., 2001).

Since gadolinum returned the $\left[\mathrm{Ca}^{2+}\right]_{\mathrm{i}}$ from the plateau level to the basal level, these results suggest that $\mathrm{Ca}^{2+}$ entry occurs through CCE mechanism in astrocytes. However, gadolinum can also inhibit L- and Ntype voltage-dependent calcium channels that are expressed on some astrocytes (Sontheimer, 1994; Agrawal et al., 2000). $\mathrm{Ca}^{2+}$ entry across the plasma membrane was not mediated by L-type voltage-sensitive $\mathrm{Ca}^{2+}$ channels because verapamil did not affect $\left[\mathrm{Ca}^{2+}\right]_{\mathrm{i}}$ levels but we cannot rule out that $\mathrm{N}$-type channels contribute to calcium entry. As in other nonexcitable cells exposed to agents mobilizing calcium from endoplasmic reticulum (Matsumoto et al., 1986; Kotlikoff et al., 1987), the initial component of the biphasic $\left[\mathrm{Ca}^{2+}\right]_{\mathrm{i}}$ increase observed after application of DETANONOate was insensitive to the removal of extracellular $\mathrm{Ca}^{2+}$, indicating that it was due to mobilization of $\mathrm{Ca}^{2+}$ from intracellular stores. Depletion of intracellular $\mathrm{Ca}^{2+}$ could provide a sufficient signal for activation of $\mathrm{Ca}^{2+}$ entry through the plasma membrane as extracellular $\mathrm{Ca}^{2+}$ is required for the generation and maintenance of the sustained $\left[\mathrm{Ca}^{2+}\right]_{\mathrm{i}}$ plateau during prolonged application of DETA-NONOate. The NOinduced glutamate release from astrocytes found here was fast-faster than the response time of the continuous assay (Fig. 2) - and terminated when the added NO was likely to have disappeared from the medium, 
so further $\mathrm{NO}$ addition caused more glutamate release. This suggests that the effect was mediated by NO itself, rather than one of its derivatives (peroxynitrite, $\mathrm{NO}_{2}, \mathrm{~N}_{2} \mathrm{O}_{3}$, or S-nitrosothiols), as it would take time for these derivatives to be produced from NO. Virtually all rapid, reversible effects of $\mathrm{NO}$ are mediated by $\mathrm{NO}$ binding to hemeproteins, such as soluble guanylate cyclase or cytochrome oxidase (Xu et al., 1998; Eu et al., 2000). However, neither of these hemeproteins appears to mediate the NO-induced glutamate release from astrocytes as release was not prevented by an inhibitor of soluble guanylate cyclase (ODQ) and release was not induced by an inhibitor of cytochrome oxidase (azide). Willmott et al. (2000a) found that NO-induced calcium waves in astrocytes were eliminated by high concentrations of ryanodine, suggesting that NO activates ryanodine receptor-mediated calcium release from endoplasmic reticulum. NO can elevate calcium in heart and skeletal muscle by S-nitrosating or oxidizing ryanodine receptors (Eu et al., 2000). This has not been reported in astrocytes, but as astrocytes express the R3 isoform of ryanodine receptors (Matyash et. al, 2002), a possible mechanism by which $\mathrm{NO}$ elevates calcium in astrocytes is by S-nitrosating or promoting thiol oxidation of the ryanodine receptor to cause release from the endoplasmic reticulum.

The mechanisms by which ATP is released from astrocytes are still unclear. In our present studies, NOinduced ATP release was entirely calcium-dependent and blocked by BoTx-C, suggesting vesicular exocytosis. Indeed, ATP has been identified as a storage component of astrocytic vesicles released from cultured astrocytes (Maienschein et al., 1999) by receptor-mediated mechanisms (Queiroz et al., 1997). Calcium-dependent ATP release from astrocytes was also reported in response to excitatory amino acids like N-methyl-Daspartate (NMDA) and kainite (Queiroz et al., 1999). However, other mechanisms of ATP release have been reported, for example, through connection hemichannels (Cotrina et al., 1998b; Stout et al., 2002) or calcium-independent mechanism after stimulation of alpha-amino-3-hydroxy-5-methylisoxazole-4-propio (ATP) receptors (Queiroz et al., 1999).

Recently, it has been shown that ATP released from astrocytes mediates increases in cytosolic calcium and propagation of calcium waves in glia (Cotrina et al., 1998a; James and Butt, 2001). ATP-dependent calcium signaling in astrocytes is mediated by metabotropic purinergic P2Y receptors (coupled to calcium release from internal stores) (Guthrie et al., 1999; Fam et al., 2000). ATP apparently also mediates calcium signaling between astrocytes and microglia through P2X purinergic receptor located on microglia (Verderio and Matteoli, 2001). ATP-mediated increase in intracellular calcium was also observed after the mechanical stimulation of astrocytes in culture (Stout et al., 2002). Interestingly, ATP can also cause a dose-dependent release of glutamate and aspartate from cultured rat astrocytes (Jeremic et al., 2001). In the present studies, we have shown that NO induced both ATP and gluta- mate release but we have not studied whether the NO-induced ATP release potentiates glutamate release or vice versa, as has been suggested in other studies (Queiroz et al., 1999). However, the NO-induced increase in extracellular ATP observed in our studies is rather low $(5.8 \pm 0.7 \mathrm{nM})$, and whether it could play a significant role in intercellular signaling needs further investigation.

Physiologically, in the brain NO is mainly produced by nNOS in subpopulation of neurons, and this nNOS is transiently activated by calcium elevations during neuronal activity (Vincent, 1994; Baader and Schilling, 1996; Baltrons et al., 1997). This suggests the possibility that NO released from active neurons may cause calcium waves in and glutamate (and ATP) release from surrounding astrocytes, and thus might be involved in neuronal-astrocytic communication and could particularly affect synaptic transmission as astrocytes and their processes surround synapses (Parpura et al., 1994; Bezi and Volterra, 2001). eNOS is expressed in some astrocytes and has been suggested to be involved in initiation and propagation of calcium waves (Willmott et al., 2000b), and thus potentially astrocytic eNOS might regulate glutamate and ATP release from astrocytes. Whether neurons or astrocytes locally release sufficient NO to cause significant glutamate or ATP release from astrocytes is unclear, but levels of NO up to $100 \mathrm{nM}$ have been measured by electrode in brain slices induced by electrical stimulation (Shibuki and Kimura, 1997), up to $1 \mu \mathrm{M}$ NO released from cultured aortic endothelial cells induced by bradykinin (Clementi et al., 1999), and up to 1-4 $\mu \mathrm{M}$ has been measured in rat brain in vivo during ischemia and reperfusion (Malinski et al., 1993). The NO released during ischemia or reperfusion might trigger extensive glutamate release from astrocytes, which could contribute to the known pathological glutamate release in these conditions (Szatkowski and Attwell, 1994; Rossi et al., 2000).

In a wide range of brain pathologies, astrocytes and microglia become activated by inflammatory mediators to express iNOS (Wisniewski et al., 1998; Murphy, 2000). In culture, activated glia can kill cocultured neurons by NO and excitotoxic mechanisms (Chao, 1996; Kingham et al., 1999; Bal-Price and Brown, 2001). Such activated astrocytes and microglia continuously produce an extracellular NO level of about $1 \mu \mathrm{M}$ (Brown et al., 1995; Bal-Price and Brown, 2001), sufficient to cause substantial glutamate release from astrocytes according to our results here. And indeed we have shown here that activated astrocytes maintain a substantially higher extracellular glutamate level, which appears to be due to enhanced glutamate release rather than reduced uptake. It has previously been reported (Ye and Sontheimer, 1998) that uptake of glutamate into astrocytes is inhibited by NO or inflammatory activation; however, the level of inhibition reported was relatively small (about 30\%), such that it would be unlikely to contribute substantially to an elevated extracellular glutamate level. We found no 
obvious inhibition of glutamate uptake by activated astrocytes, but our data are not sufficient to rule out a small inhibition of the order of $30 \%$. According to other data (Patneau and Mayer, 1990), the level of extracellular glutamate we find maintained by activated astrocytes would be sufficient to activate NMDA receptors and therefore might contribute to the mechanisms by which activated glia kill neurons in coculture. Thus, NO-induced release of glutamate from astrocytes potentially might contribute to neuronal death during all the inflammatory, infectious, ischemic, and neurodegenerative diseases where iNOS has been shown to be expressed in glia (Eddleston and Mucke, 1993; Kreutzberg, 1996).

\section{ACKNOWLEDGMENT}

The authors thank Dr Edward Bamtpon for preparing the fibroblast culture.

\section{REFERENCES}

Agrawal SK, Nashmi R, Fehlings MG. 2000. Role of L- and N-type calcium channels in the pathophysiology of traumatic spinal cord white matter injury. Neuroscience 99:179-188.

Araque A, Li N, Doyle RT, Haydon PG. 2000. SNARE protein-dependent glutamate release from astrocytes. J Neurosci 20:666-673.

Baader SL, Schilling K. 1996. Glutamate receptors mediate dynamic regulation of nitric oxide synthase expression in cerebellar granule cells. J Neurosci 16:1440-1449.

Bal A, Bachelot T, Savasta M, Manier M, Verna JM, Benabid AL, Feuerstein C. 1994. Evidence for dopamine $\mathrm{D}_{2}$ receptor mRNA expression by striatal astrocytes in culture: in situ hybridization and polymerise chain reaction studies. Mol Brain Res 23:204-212.

Bal-Price A, Brown GC. 2001. Inflammatory neurodegeneration mediated by nitric oxide from activated glia-inhibiting neuronal respiration, causing glutamate release and excitotoxicity. J Neurosci 21:6480-6491.

Baltrons MA, Saadoun S, Agullo L, Garcia A. 1997. Regulation by calcium of the nitric oxide/cyclic GMP system in cerebellar granule cells and astroglia in culture. J Neurosci Res 49:333-341.

Barbier AJ, Lefebvre RA. 1992. Effect of LY 83583 on relaxation induced by non-adrenergic non-cholinergic nerve stimulation and exogenous nitric oxide in the rat gastric fundus. Eur J Pharmacol 219:331-334.

Bezzi P, Carmignoto G, Pasti L, Vesce S, Rossi D, Rizzini BL, Pozzan T, Volterra A. 1998. Prostaglandins stimulate calcium-dependent glutamate release in astrocytes. Nature 391:281-285.

Bezzi P, Volterra A. 2001. A neuron-glia signalling network in the active brain. Curr Opin Neurobiol 11:387-394.

Bolanos JP, Almeida A. 1999. Role of nitric oxide in brain hypoxiaischaemia. Biochim Biophys 1411:415-436.

Bowman CL, Yohe L, Lohr JW. 2001. Regulation of cytoplasmic calcium levels by two nitric oxide receptors. Am J Physiol 281:876885.

Brown GC, Bolanos JP, Heals SJ, Clark JB. 1995. Nitric-oxide produced by activated astrocytes rapidly and reversibly inhibits cellular respiration. Neurosci Lett 193:201-204.

Chao CC. 1996. Cytokine-stimulated astrocytes damage human neurons via a NO mechanism. Glia 16:276-284.

Clementi E, Brown GC, Foxwell N, Moncada S. 1999. On the mechanism by which vascular endothelial cells regulate their oxygen consumption. Proc Natl Acad Sci USA 96:1559-1562.

Cohen J, Wilkin GP. 1995. Neuronal cell culture. New York: Oxford University Press.

Cotrina ML, Lin JHC, Nedergaard M. 1998a. Cytoskeletal assembly and ATP release regulate astrocytic calcium signaling. J Neurosci 18:8794-8804

Cotrina ML, Lin JHC, Nedergaard M. 1998b. Connexins regulate calcium signaling by controlling ATP release. Proc Natl Acad Sci USA 95:15735-15740.
Dinerman JL, Dawson TM, Schell MJ, Snowman A, Snyder SH. 1994 Endothelial nitric oxide synthase localized to hippocampal pyramidal cells: implications for synaptic plasticity. Proc Natl Acad Sci USA 91:4214-4218.

Eddleston M, Mucke L. 1993. Molecular profile of reactive astrocytes: implications for their role in neurologic disease. Neuroscience 54: $15-36$.

Eu IP, Sun I, Xu L, Stamler JS, Meissner G. 2000. The skeletal muscle calcium release channel: coupled $\mathrm{O}_{2}$ sensor and NO signaling functions. Cell 102:499-509.

Fam SR, Gallagher CJ, Salter MW. 2000. P2Y1, purinoreceptor-mediated $\mathrm{Ca}^{2+}$ signaling and $\mathrm{Ca}^{2+}$ waves propagation in dorsal spinal cord astrocytes. J Neurosci 20:2800-2808.

Garthwaite J, Boulton CL. 1995. Nitric oxide signaling in the central nervous system. Ann Re Physiol 57:683-706.

Goodwin Jl, Uemura E, Cunnick JE. 1995. Microglial release of nitric oxide by the synergistic action of beta-amyloid and IFN-gamma. Brain Res 692:207-214.

Guthrie PB, Knappenberger J, Segal M, Bennett MVL, Charles AC. 1999. ATP released from astrocytes mediates glial calcium waves. J Neurosci 19:520-528.

Heales SJR, Bolanos JP, Stewart VC, Brookes PS, Land JM, Clark JB. 1999. Nitric oxide, mitochondria and neurological disease. Biochim Biophys Acta 1410:215-228.

Hewett SJ, Csernansky CA, Choi DW. 1994. Selective potentiation of NMDA-induced neuronal injury following induction of astrocytic iNOS. Neuron 13:487-494.

Ignarro LJ. 2000. Nitric oxide: biology and pathology. San Diego, CA: Academic Press.

Innocenti B, Parpura V, Haydon PG. 2000. Imaging extracellular waves of glutamate during calcium signalling in cultured astrocytes. J Neurosci 20:1800-1808.

James G, Butt AM. 2001. P2X and P2Y purinoreceptors mediate ATP-evoked calcium signalling in optic nerve glia in situ. Cell Calcium 30:251-259.

Jeftinja SD, Jeftinija KV, Stefanovic G. 1997. Cultured astrocytes express proteins involved in vescicular glutamate release. Brain Res 750:41-47.

Jeremic A, Jeftinija K, Stevanovic J, Glavaski A, Jeftinija S. 2001. ATP stimulates calcium-dependent glutamate release from cultured astrocytes. J Neurochem 77:664-675.

Kingham PJ, Cuzner ML, Pocock JM. 1999. Apoptotic pathways mobilized in microglia and neurons as a consequence of chromogranin A-induced microglial activation. J Neurochem 73:538-547.

Knott C, Stern G, Wilkin GP. 2000. Inflammatory regulators in Parkinson's disease: iNOS, lipocortin-1, and cyclooxygenases-1 and -2 . Mol Cell Neurosci 16:724-739.

Kotlikoff ML, Murray RK, Reynolds EE. 1987. Histamine-induced calcium release and phorbol antagonism in cultured airway smooth muscle cells. Am J Physiol 253:561-566.

Kreutzberg GW. 1996. Microglia: a sensor for pathological events in the CNS. TINS 19:312-318.

Lee SC, Zhao ML, Hirano A, Dickson DW. 1999. Inducible nitric oxide synthase immunoreactivity in the Alzheimer disease hippocampus: association with Hirano bodies, neurofibrillary tangles, and senile plaques. J Neuropathol Exp Neurol 58:1163-1169.

Leist M, Fava E, Montecucco C, Nicotera P. 1997. Peroxynitrite and nitric oxide donors induce neuronal apoptosis by eliciting autocrine excitotoxicity. Eur J Neurosci 9:1488-1498.

Lim GP, Yang F, Chu T, Chen P, Beech W, Teter B, Tran T, Ubeda O Ashe KH, Frautschy SA, Cole GM. 2000. Ibuprofen suppresses plaque pathology and inflammation in a mouse model for Alzheimer's disease. J Neurosci 20:5709-5714

Loihl AK, Murphy S. 1998. Expression of NOS-2 in glia associated with CNS pathology. Prog Brain Res 118:253-267.

Maienschein V, Marxen M, Volknandt W, Zimmermann H. 1999. A plethora of presynaptic proteins associated with ATP-storing organelles in cultured astrocytes. Glia 26:233-244.

Malinski T, Bailey F, Zhang ZG, Chopp M. 1993. Nitric oxide measured by a porphyrinic microsensor in rat brain after transient middle cerebral artery occlusion. J Cereb Blood Flow Metab 13:355358.

Matsumoto T, Kanaide H, Nishimura, Shogakiuchi Y, Kobayashi S, Nakamura. 1986. Histamine activates $\mathrm{H}_{1}$ receptors to induce cytosolic free calcium transients in cultured vascular smooth muscle cells from rat aorta. Biochem Biophysic Res 135:172-177.

Matyash V, Filippov V, Mohrhagen K, Kettenmann H. 2001. Nitric oxide signals parallel fiber activity to Bergmann glial cells in the mouse cerebellar slice. Mol Cell Neurosci 18:664-670.

Matyash M, Matyash V, Nolte C, Sorrentino V, Kettenmann H. 2002. Requirement of functional ryanodine receptor type 3 for astrocytes migration. FASEB 16:84-86. 
Mazzanti M, Sul JY, Haydon PG. 2001. Glutamate on demand; astrocytes as a ready source. Neuroscientist 7:396-405.

McNaught KSP, Brown GC. 1998. Nitric oxide causes glutamate release from brain synaptosomes following inhibition of mitochondrial function. J Neurochem 70:1541-1546.

McGeer EG, McGeer PL. 1995. Brain inflammation in Alzheimer disease and the therapeutic implications. Curr Pharm Des 10:821836.

McGeer PL, Schulzer M, McGeer EG. 1996. Arthritis and anti-inflammatory agents as possible protective factors for Alzheimer's disease: a review of 17 epidemiologic studies. Neurology 47:425-432.

Meffert MK, Premack BA, Schulman H. 1994. Nitric oxide stimulates $\mathrm{Ca}^{+2}$-independent synaptic vesicle release. Neuron 12:1235-1244.

Meffert MK, Calakos NC, Scheller RH, Schulman H. 1996. Nitric oxide modulates synaptic vesicle docking/fusion reactions. Neuron 16:1229-1236.

Moneer Z, Taylor CW. 2002 Reciprocal regulation of capacitative and non-capacitative $\mathrm{Ca}^{2+}$ entry in A7r5 vascular smooth muscle cells: only the latter operates during receptor activation. Biochem J 362: $13-21$

Murphy S. 2000. Production of nitric oxide by glial cells: regulation and potential roles in the CNS. Glia 29:1-14.

Nicholls DG, Sihra TS, Sanchez-Prieto J. 1987. Calcium-dependent and -independent release of glutamate from synaptosomes monitored by continuous fluorometry. J Neurochem 49:50-57.

Parpura V, Basarsky TA, Liu F, Jeftinija K, Jeftinija S, Haydon PG. 1994. Glutamate-mediated astrocyte-neuron signalling. Nature 369:744-747.

Pasti L, Zonta M, Pozzan T, Vicini S, Carmingnoto G. 2001. Cytosolic calcium oscillations in astrocytes may regulate exocytotic release of glutamate. J Neurosci 21:477-484

Patneau DK, Mayer ML. 1990. Structure-activity relationships for aminoacid transmitter candidates acting at N-methyl-D-aspartate and quisqualate receptors. J Neurosci 10:2385-2399.

Pauwels PJ, Opperdoes FR, Trouet A. 1985. Effects of antimycin, glucose deprivation, and serum on cultures of neurons, astrocytes, and neuroblastoma cells. J Neurochem 44:143-148.

Peuchen S, Bolanos JP, Heals SJR, Almeida A, Duchen MR, Clark JB. 1997. Interrelations between astrocytes function, oxidative stress and antioxidant status within the central nervous system. Prog Neurobiol 52:261-281.

Prast H, Philippu A. 2001. Nitric oxide as modulator of neuronal function. Prog Neurobiol 64:51-68.

Queiroz G, Gebicke-Haerter PJ, Schobert A, Starke K, von Kugelgen I. 1997. Release of ATP from cultured rat astrocytes elicited by glutamate receptor activation. Neuroscience 78:1203-1208.

Queiroz G, Meyer DK, Meyer A, Starke K, von Kugelgen I. 1999. A study of the mechanism of the release of ATP from rat cortical astroglial cells evoked by activation of glutamate receptors. Neuroscience $91: 1171-1181$.
Rossi DJ, Oshima T, Attwell D. 2000. Glutamate release in severe brain ischaemia is mainly by reversed uptake. Nature 403:316-321. Scemes E. 2000. Components of astrocytic intercellular calcium signaling. Mol Neurobiol 22:167-179.

Sequeira S, Ambrosio A, Malva JO, Carvalho AP, Carvalho CM. 1997. Modulation of glutamate release from rat hippocampal synaptosomes by nitric oxide. Nitric Oxide Biol Chem 1:315-329.

Shibuki K, Kimura S. 1997. Dynamic properties of nitric oxide release from parallel fibers in rat cerebellar slices. J Physiol 15:443-452.

Sontheimer H. 1994. Voltage-dependent ion channels in glial cells. Glia 11:156-172.

Stout CE, Constantin JL, Naus CC, Charles AC. 2002. Intercellular calcium signaling in astrocytes via ATP release through connexin hemichannels. J Biol Chem 10:1074-1084.

Szatkowski M, Attwell D. 1994. Triggering and execution of neuronal death in brain ischaemia: two phases of glutamate release by different mechanisms. TINS 17:359-365.

Taupenot L, Ciesielski-Treska J, Urlich G, Chasserot-Golaz S, Aunis D, Bader MF. 1996. Chromogranin A triggers a phenotypic transformation and the generation of nitric oxide in brain microglial cells. Neuroscience 72:377-389.

Trabace L, Kendrick KM. 2000. Nitric oxide can differentially modulate striatal neurotransmitter concentrations via soluble guanylate cyclase and peroxynitrite formation. J Neurochem 75:1664-1674.

Wa J, Food MR, Gabathuler R, Rothenberger S, Yamada T, Yasuhara O, McGeer PL. 1996. Reactive microglia specifically associated with amyloid plaques in Alzheimer's disease brain tissue express melanotransferrin. Brain Res 712:122-126.

Wallace MN, Geddes JG, Farquhar DA, Masson MR. 1997. Nitric oxide synthase in reactive astrocytes adjacent to beta-amyloid plaques. Exp Neurol 144:266-272.

Verderio C, Matteoli M. 2001. ATP mediates calcium signaling between astrocytes and microglial cells: modulation by IFN-gamma. J Immunol 166:6383-6391.

Vincent SR. 1994. Nitric oxide: a radical neurotransmitter in the central nervous system. Prog Neurobiol 42:129-160.

Willmott NJ, Wong K, Strong A. 2000a. A fundamental role for the nitric-oxide-G-kinase signaling pathway in mediating intracellular $\mathrm{Ca}^{2+}$ waves in glia. J Neurosci 20:1767-1779.

Willmott NJ, Wong K, Strong AJ. 2000b. Intercellular $\mathrm{Ca}^{2+}$ waves in rat hippocampal slice and dissociated glial-neuron cultures mediated by nitric oxide. FEBS Lett 487:239-247.

Wisniewski HM, Wegiel J, Wisniewski T. 1998. Pathogenesis of amyloid- $\beta$ plaques: activated microglia the cause of fibrillar amyloid formation and neuropil degeneration. Neurosci News 1:30-34.

Xu L, Eu JP, Meissner G, Stamler JS. 1998. Activation of the cardiac calcium release channel, rayanodine receptor, by poly-S-nitrosylation. Science 279:234-237.

Ye Z, Sontheimer H. 1998. Glial glutamate transport as target for nitric oxide: consequences for neurotoxicity. Prog Brain Res 118: 241-251. 